\title{
Fractions and isolated compounds from Lansium domesticum fruit peel exhibited cytotoxic activity against T-47D and HepG2 cell lines
}

\author{
KHUSNUL FADHILAH ${ }^{1}$, SUBAGUS WAHYUONO ${ }^{2, \boldsymbol{v}}$, PUJI ASTUTI ${ }^{2}$ \\ ${ }^{1}$ Faculty of Pharmacy, Universitas Gadjah Mada. Jl. Sekip Utara, Sleman 55281, Yogyakarta, Indonesia \\ ${ }^{2}$ Department of Pharmaceutical Biology, Faculty of Pharmacy, Universitas Gadjah Mada. J1. Sekip Utara, Sleman 55281, Yogyakarta, Indonesia. \\ Tel./fax.: +62-274-543120, `email: subagusw_fa@ugm.ac.id
}

Manuscript received: 9 July 2021. Revision accepted: 17 July 2021.

\begin{abstract}
Fadhilah K, Wahyuono S, Astuti P. 2021. Fractions and isolated compounds from Lansium domesticum fruit peel exhibited cytotoxic activity against T-47D and HepG2 cell lines. Biodiversitas 22: 3743-3748. Lansium domesticum (Fam. Meliaceae), a tropical fruit (local name, Duku), has been reported to have various biological activities- At the moment we emphasize on searching compounds to have cytotoxic activity from the peel of L. domesticum. The study was initiated by extraction with EtOAc followed by fractionation that was monitored by thin-layer chromatography (TLC) and cytotoxicity against T-47D and HepG2 cells. The EtOAc extract of the sample was triturated with $n$-hexane to give $n$-hexane soluble (A) $n$-hexane insoluble fractions (B). The B fraction was fractionated by vacuum column chromatography using gradient solvent composition of $n$-hexane: acetone to give 18 fractions. According to TLC similarity pictures, fractions were combined to give 6 fractions (I-VI). Isolation was performed using preparative TLC, and the cytotoxic assay was performed using MTT method. The isolated compound was identified as a sesquiterpene having one aldehyde functional group, based on spectroscopic data.The isolated compound displayed cytotoxic activity on T-47D (IC $50,48.58 \pm 0.96 \mu \mathrm{g} / \mathrm{mL})$ and HepG2 (IC50, $127.45 \pm 25.76 \mu \mathrm{g} / \mathrm{mL})$.
\end{abstract}

Keywords: Cytotoxic, HepG2, Lansium domesticum, T-47D

Abbreviations: DMEM: Dulbecco's Modified Eagle Medium; DMSO: Dimethyl Sulfoxide; EtOAc: Ethyl Acetate; GC-MS: Gas Chromatography-Mass Spectrometry; HepG2: Human Hepatocarcinoma Cell Line; MTT: 3-(4,5-dimethyl-thiazol-2-yl)-2,5-diphenyltetrazolium bromide); NMR: Nuclear Magnetic Resonance; RPMI: Roswell Park Memorial Institute; T-47D: Human Breast Cancer Cell Line; TLC: Thin Layer Chromatography; VLC : Vacuum Liquid Chromatography

\section{INTRODUCTION}

Lansium domesticum (known as Duku fruit in Indonesia) is generally consumed by people in some countries in Asia for its nutritional content. Lansium domesticum is a plant from the Meliaceae family spread in various regions in Indonesia and Southeast Asia. This plant has a synonym Lansium parasiticum (Osbeck) K.C. Sahni \& Bennet. In Indonesia, this plant is known as duku, langsat, and kokosan. While in other countries, it is known as longkong (Thailand), langseh (Malaysia) and bon-bon (Vietnam). Traditionally, its fruit peel is used to treat diarrhea and used as mosquitoes repellent. In addition, the fruit peel combined with the stem was used as arrow poison. The decoction of the stems of $L$. domesticum and bark of Pterocarpus indica help treat dysentery while the seeds are used to treat fever. The resinous rind of the fruit is used to help treat diarrhea and colitis. Burnt fruit skin is used as a mosquito repellent. The bark is used to treat scorpion stings and malaria. Meanwhile, the leaves are used to help relieve inflammation (Mayanti 2009). Some studies showed that the Duku fruit peel contains several chemical compounds and biological activities. Based on the studies reported in 2015, extracts and fractions from $L$. domesticum fruit peel had antioxidant activity. They had scavenging free radicals (DPPH) and contain phenolic compounds (Kee et al. 2015). 3-Hydroxy-8,14secogammacera-7,14-dien-21-one isolated from $L$. domesticum fruit peel, showed cytotoxic activity on MCF-7 breast cancer cells with an $\mathrm{IC}_{50}$ of $717.5 \mu \mathrm{M}$ (Zulfikar et al. 2020). Lansioside D, a triterpenoid glycoside compound, has antibacterial activity on Staphylococcus aureus, Bacillus subtilis, and Escherichia coli (Marfori et al. 2015). The ethanol-ethyl acetate fraction $(50: 50 \%, \mathrm{v} / \mathrm{v})$ of Duku bark has DNA damage-preventing activity on lymphoblast cells induced by $\mathrm{H}_{2} \mathrm{O}_{2}$ exposure at doses of $25,50,100$, and $200 \mu \mathrm{g} / \mathrm{mL}$ (Klungsupya et al. 2015). There were tetranortriterpenoids langsatides $\mathrm{A}$ and $\mathrm{B}$ were isolated from $L$. domesticum seed and showed weak cytotoxic and antibacterial activities $\left(\mathrm{IC}_{50}>100 \mu \mathrm{M}\right)$ (Rudiyansyah et al. 2018). Onoceranoid type triterpenoid from the methanolic extract of L.domesticum leaves is known to have antimutagenic effect (Matsumoto et al. 2018). Triterpenoid 8,14-Secogammacera-7,14(27)-dien-3,21-dione was isolated from the fruit peel. This compound showed cytotoxicity against HeLa, T-47D and A549 cell lines with $\mathrm{IC}_{50}$ value $32.39 \pm 1.17,30.69 \pm 1.87$, dan $13.71 \pm 0.42$ $\mu \mathrm{g} / \mathrm{ml}$ (Labibah et al. 2021). Obebioside A, hongelin and obeside B from the leaves showed inhibition notch signaling that play role in cancer progression. These compounds showed $\mathrm{IC}_{50}$ values $1.65 \mu \mathrm{M}, 0.62 \mu \mathrm{M}$, and $0.51 \mu \mathrm{M}$ (Tsuchiya et al. 2020). Considering the diversity 
and potential bioactivity of this plant, research is still needed to explore the compounds within Duku fruit peel and their biological activity. In this study, extraction and fractionation were carried out to determine the diversity profiles of the Duku fruit peel and their potential cytotoxic activity against T-47D and HepG2 cells.

\section{MATERIALS AND METHODS}

Material L. domesticum fruit peel was collected from Purbalingga, Central Java, Indonesia and identified in Department of Biology, Faculty of Pharmacy, Universitas Gadjah Mada, Yogyakarta, Indonesia. Solvents used were p.a grades from E Merck. Silica gel $\mathrm{F}_{254}$ were used for thinlayer chromatography dan Silica gel $\mathrm{PF}_{254}$ for preparative thin layer chromatography (Merck), Cerium (IV) sulfate tetrahydrate (E Merck), RPMI 1640, Fetal Bovine Serum, Penicillin-Streptomycin, Fungizon, Sodium bicarbonate (Gibco), HEPES (Invitrogen), Phosphate Buffered Saline, MTT, Doxorubicin (Sigma Aldrich). The T-47D and HepG2 cell lines were collection from Parasitology Laboratory, Faculty of Medicine, Public Health and Nursing, Universitas Gadjah Mada, Yogyakarta, Indonesia. Mass spectra were obtained from GC-MS (Shimadzu). Spectra of ${ }^{1} \mathrm{H}$ - and ${ }^{13} \mathrm{C}$ - NMR $\left(\mathrm{CDCl}_{3}\right)$ were measured using JEOL JNM-ECZ 500R/S1 at $500 \mathrm{MHz}$. Infrared $(\mathrm{KBr})$ spectrum was obtained from spectrophotometer (Shimadzu). Ultraviolet spectrum $\left(\mathrm{CHCl}_{3}\right)$ was obtained from UV spectrophotometer (Hitachi UH 5300).

\section{Extraction and vacuum liquid chromatography (VLC)}

The peels were separated from the fruit and dried in an oven at $50{ }^{\circ} \mathrm{C}$ as previously described (Fadhilah et al. 2020). The dried peels were macerated with ethyl acetate by maceration method three times at room temperature. The macerate was evaporated using a rotary evaporator at a temperature of $50{ }^{\circ} \mathrm{C}$ to obtain a thick ethyl acetate extract. The EtOAc extract was triturated with n-hexane to give nhexane (A) and insoluble fractions (B). Fraction B was further fractionated by vacuum column chromatography (VLC) to give fractions B1-B5. Fractions B3-B5 which showed similar TLC profiles and contained a major compound were combined and separated using VLC (nhexane: acetone, gradient polarity) to give 18 fractions ( $\mathrm{Fr}$ $1-$ Fr 18). The fractions that have similar TLC profiles were combined to give 6 fractions (Fr I-VI). Fraction III that showed a major compound was isolated by preparative TLC double development [silica gel $\mathrm{PF}_{254}, 1^{\text {st }}$ mobile phase (n-hexane: Acetone 6:1) and $2^{\text {nd }}$ mobile phase (chloroform: acetone 10: 0.5$)$ ], to give the intended compound.

\section{Cytotoxic activity assay}

The cytotoxic activity test was performed according to previous method with some modification (Bahuguna et al. 2017). A hundred $\mu \mathrm{l}$ of cells in RPMI media were placed into 96 well microplates to obtain $10^{4}$ cells/well and incubated for 24 hours (temperature $37{ }^{\circ} \mathrm{C}$ and $5 \% \mathrm{CO}_{2}$ ). The cells were treated with the test sample and incubated for 24 hours. The test sample (fractions and isolated compound in DMSO) was made in a series of concentrations of $150 ; 125 ; 100 ; 75 ; 50 \mu \mathrm{g} / \mathrm{mL}$ and doxorubicin was used as a positive control with concentrations of $2 ; 1 ; 0.5 ; 0.25 ; 0.125 ; 0.0625, \mu \mathrm{g} / \mathrm{mL}$ After treatment, the culture media was removed and replaced with $100 \mu \mathrm{l} /$ well of MTT reagent $(5 \mathrm{mg} / \mathrm{mL})$ and incubated for 4 hours. After incubation, $100 \mu \mathrm{L}$ of stopper solution (SDS 10\%) was added and the plates were let to stand at room temperature overnight. Absorbance was measured with a microplate reader (BioRad) at $595 \mathrm{~nm}$. The data generated were used to plot a dose-response curve and $\mathrm{IC}_{50}$ of samples was determined. The $\mathrm{IC}_{50}$ values were analyzed by one-way ANOVA with statistical significance $\mathrm{P}<0.05$ using IBM SPSS ver. 23 .

\section{RESULTS AND DISCUSSION}

\section{Secondary metabolites profile}

Based on a reported study, parts of L. domesticum contain various chemical compounds. Based on GC-MS analysis, L. domesticum fruit extract contains terpenoids and fatty acids such as $\alpha$-cadinol, (-)-spathulenol, $\alpha$ muurolene, $\alpha$-cubebene, octadecanoic acid, 1,2,3,4tetrahydro-1,1,6-trimethyl-naphthalene, and hexadecanoic acid (Manosroi et al. 2012). The fruit peel contains phenolic compounds such as rutin, skopoletin, and chlorogenic acid (Klungsupya et al. 2015). Besides, the methanolic extract of the seeds contains alkaloid, flavonoid, terpenoid, saponin, and tannin (Konda et al. 2020). This study analyzed the components within $L$. domesticum fruit peel extract was carried out using TLC. The profile analysis of secondary metabolites was conducted using silica gel $\mathrm{F}_{254}$ as stationary phase and nhexane-ethyl acetate $(4: 1) \mathrm{v} / \mathrm{v}$ as the mobile phase. The TLC profiles were examined under $\mathrm{UV}_{254}$ and $\mathrm{UV}_{366}$ light as well as spray reagent $\mathrm{Ce}\left(\mathrm{SO}_{4}\right)_{2}$. $\mathrm{Ce}\left(\mathrm{SO}_{4}\right)_{2}$ is a universal detection reagent for organic compounds which has destructive and oxidative properties (Susilo and Suciati 2016). TLC profiles showed variations of the compounds in the fractions as seen in Figure 1. Fraction I-VI showed different polarity with hRf 5-95. Fractions I and II contain compounds with hRf values 15-95, fraction III (Figure 2) contains compounds with hRf 15-60, fraction 4 contains compounds with hRf 10-35, fraction 5 contains compounds with hRf 5-35 and fraction 6 contains compounds with the lowest hRf value. In general, the higher the acetone content in the eluent composition used during fractionation, the more polar the compound content obtained. Most of the compounds showed quenching in $\mathrm{UV}_{254}$ and red-brown color after $\mathrm{Ce}\left(\mathrm{SO}_{4}\right)_{2}$ visualization. This indicated the presence of unsaturated double bond in the compound. Compound with hRf 5 and 80 showed blue fluorescent under $\mathrm{UV}_{366}$ suggesting aromatic ring or phenolic compound. Fraction III has spots with hRf values 25-70. Before being treated with reagents, all compounds showed quenching at $\mathrm{UV}_{254}$ but not gave fluorescent at $\mathrm{UV}_{366}$. The hRf 45-70 spots showed red and brownish color changes with $\mathrm{Ce}\left(\mathrm{SO}_{4}\right)_{2}$ reagent but did not show color changes with the $\mathrm{FeCl}_{3}$ reagent. $\mathrm{FeCl}_{3}$ was used for detection of phenolic 
compounds (Pascual et al. 2002). These results indicate that hRf 25-40 are phenolic compounds, while 45-70 are terpenoids or steroids. Fraction V has spot at hRf 10-50. Before reagent being applied, the hRf 25-40 spots were quenched at $\mathrm{UV}_{254}$ and only the hRf 25 spots also fluoresce blue at $\mathrm{UV}_{366}$. The compound in hRf 10-20 is red with
$\mathrm{Ce}\left(\mathrm{SO}_{4}\right)_{2}$ reagent but does not change color in the $\mathrm{FeCl}_{3}$ reagent, the spots are thought to be terpenoid or steroid compounds. While compounds 25-50 are grey with $\mathrm{FeCl}_{3}$ reagent, the presence of phenolic compounds can be predicted.

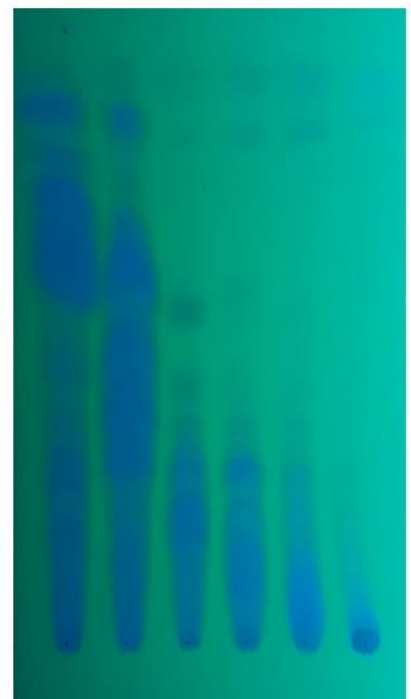

I $\quad$ II $\quad$ III $\quad$ IV $\quad$ V $\quad$ VI

A
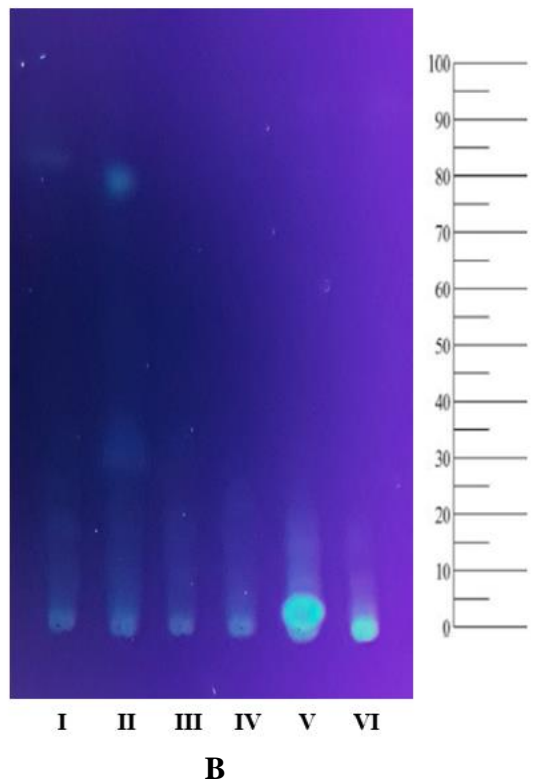

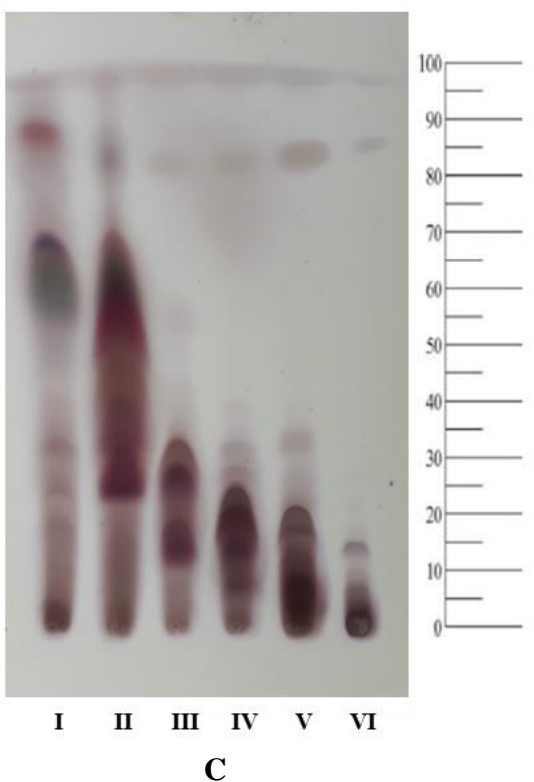

C

Figure 1. TLC profile of fractions (I-VI) obtained from n-hexane insoluble, visualized by $\mathrm{UV}_{254}(\mathrm{~A}), \mathrm{UV}_{366}(\mathrm{~B}), \mathrm{Ce}(\mathrm{SO})_{2}(\mathrm{C})$. Stationary phase: silica gel $\mathrm{F}_{254}$ dan mobile phase: n-hexane:acetone $4: 1 \mathrm{v} / \mathrm{v}$

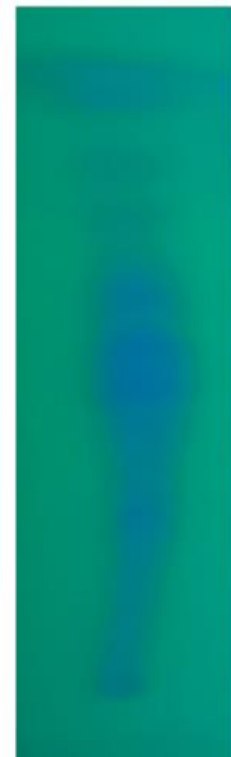

A

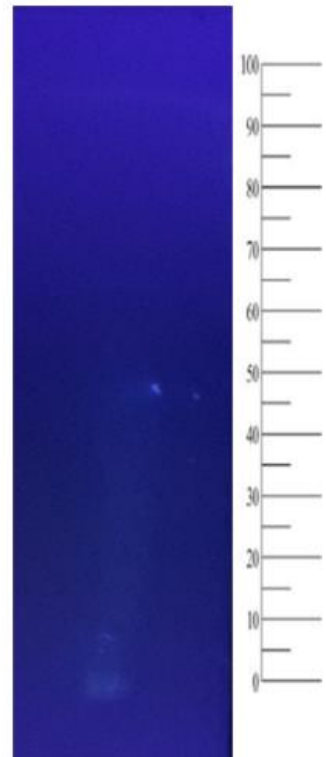

B

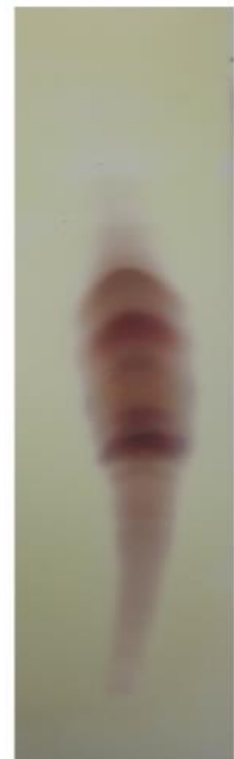

C

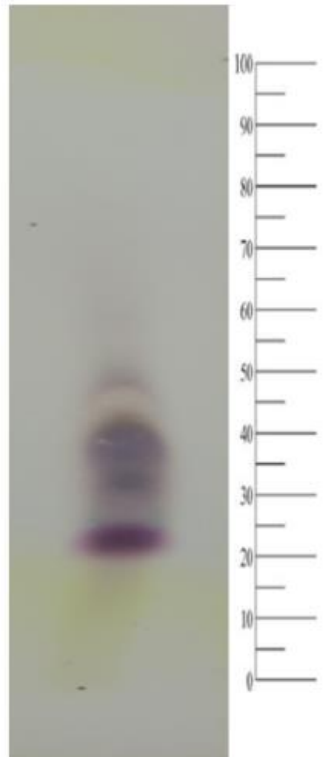

D

Figure 2. TLC profile of fraction III with visualization inUV $\mathrm{UV}_{254}(\mathrm{~A}), \mathrm{UV}_{366}(\mathrm{~B}), \mathrm{Ce}\left(\mathrm{SO}_{4}\right)_{2}(\mathrm{C}), \mathrm{FeCl}_{3}(\mathrm{D})$. Stationary phase used silica gel $\mathrm{F}_{254}$ dan mobile phase used n-hexane: acetone 3:1. 

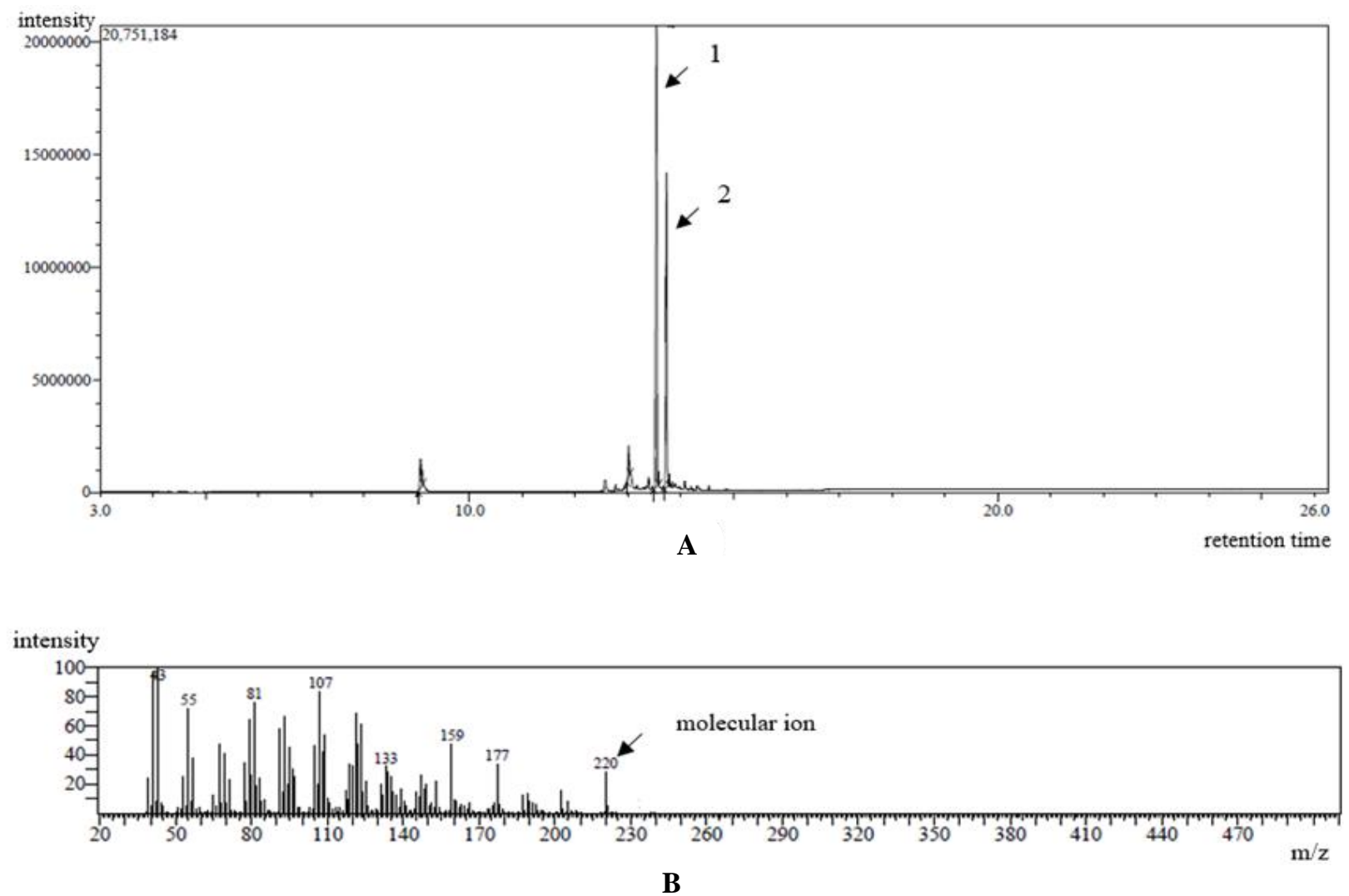

Figure 3. GC-MS spectra of the isolated compound, chromatogram (A), mass spectra of $1^{\text {st }}$ peak (B)

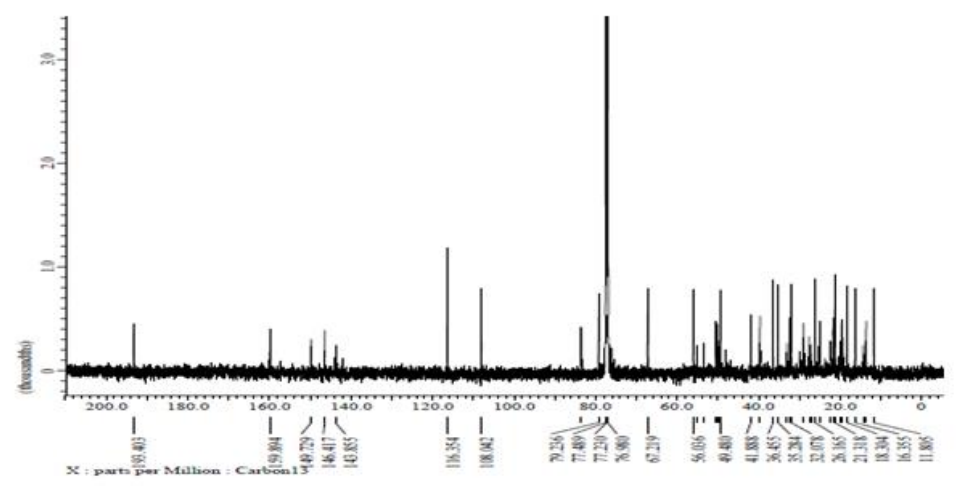

A

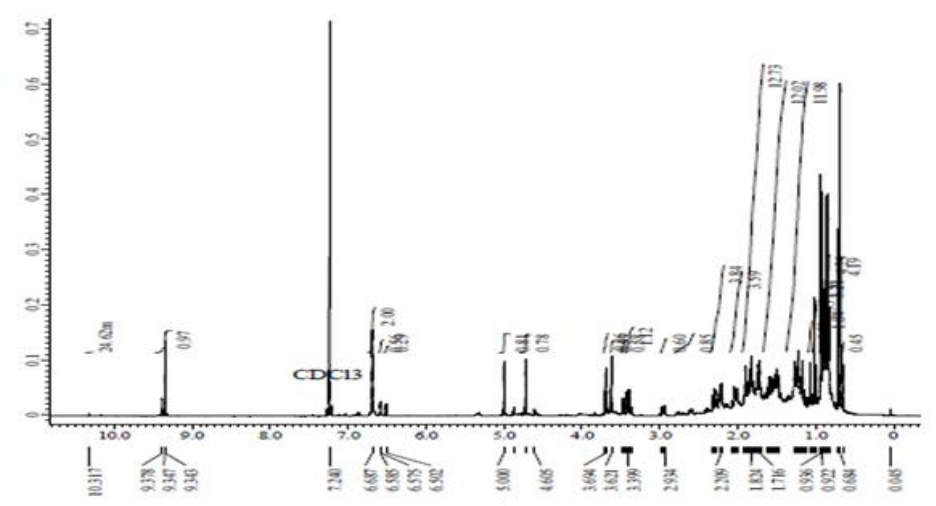

B

Figure 4. ${ }^{13} \mathrm{C}-\mathrm{NMR}$ (A) and ${ }^{1} \mathrm{H}-\mathrm{NMR}(\mathrm{B})$ spectrum of the isolated compound $\left(\mathrm{CDCl}_{3}, 500 \mathrm{MHz}\right)$. Structure of the isolated compound (C) 
Table 1. ${ }^{13} \mathrm{C}-\mathrm{NMR}$ and ${ }^{1} \mathrm{H}-\mathrm{NMR}$ table of the isolated compound

\begin{tabular}{|c|c|c|}
\hline No. & ${ }^{1}$ H NMR & ${ }^{13} \mathrm{C}-\mathrm{NMR}$ \\
\hline 1 & $9.343-9.347(1 \mathrm{H}, \mathrm{s})$ & 193 \\
\hline 2 & & 159.894 \\
\hline 3 & $6.502-6.513(1 \mathrm{H}, \mathrm{s})$ & 143.855 \\
\hline 4 & $2.269-2.319(2 \mathrm{H}, \mathrm{q})$ & 26.165 \\
\hline 5 & $1.481-1.606(3 \mathrm{H}, \mathrm{m})$ & 16.315 \\
\hline 1 , & $2.012-2.076(1 \mathrm{H}, \mathrm{m})$ & 36.455 \\
\hline 2 ' & $6.575-6.585(1 \mathrm{H}, \mathrm{s})$ & 108.042 \\
\hline 3 ' & & 146.417 \\
\hline 4 ' & $1.696-1.925(1 \mathrm{H}, \mathrm{m})$ & 56.036 \\
\hline 5, & $1.072(2 \mathrm{H}, \mathrm{m})$ & 32.087 \\
\hline 6 ' & $1.16-1.22(2 \mathrm{H}, \mathrm{m})$ & 49.48 \\
\hline 7 , & $0.83-0.85(3 \mathrm{H}, \mathrm{m})$ & 35.284 \\
\hline 8 & $2.20-2.22(1 \mathrm{H}, \mathrm{m})$ & 41.888 \\
\hline 9' & $0.922-0.936(3 \mathrm{H}, \mathrm{d}, \mathrm{J}=7 \mathrm{~Hz})$ & 18.304 \\
\hline 10 ' & $0.838-0.852(3 \mathrm{H}, \mathrm{d}, \mathrm{J}=7 \mathrm{~Hz})$ & 21.318 \\
\hline
\end{tabular}

Table 2. Cytotoxicity of n-hexane insoluble fraction and the isolated compound against cancer cell lines

\begin{tabular}{lcc}
\hline \multirow{2}{*}{ Samples } & \multicolumn{2}{c}{$\mathbf{I C}_{\mathbf{5 0}}(\boldsymbol{\mu} \mathbf{g} / \mathbf{m l})$} \\
\cline { 2 - 3 } & T-47D & HepG2 \\
\hline Fractions 1-3 (I) & $72.71 \pm 5.19$ & $62.65 \pm 1.11$ \\
Fractions 4-5 (II) & $75.64 \pm 2.49$ & $73.05 \pm 9.57$ \\
Fractions 6-9 (III) & $58.00 \pm 2.47$ & $52.31 \pm 4.21$ \\
Fractions 10-12 (IV) & $58.92 \pm 0.86$ & $101.93 \pm 2.77$ \\
Fractions 13-15 (V) & $54.66 \pm 0.69$ & $97.73 \pm 3.45$ \\
Fractions 16-18 (VI) & $97.20 \pm 1.54$ & $133.28 \pm 7.01$ \\
Isolated compound & $48.58 \pm 0.96$ & $127.45 \pm 25.76$ \\
Doxorubicin & $0.43 \pm 0.01$ & $1.18 \pm 0.09$ \\
\hline \multicolumn{2}{l}{ Note: All data are presented as mean $\pm \mathrm{SD}(\mathrm{n}=3) \mathrm{p}<0.05$}
\end{tabular}

Note: All data are presented as mean \pm SD $(n=3) p<0.05$

\section{Structure identification}

Isolated compound appeared as colorless oil, displayed maximum absorption (UV $\Lambda_{\max }$ ) at $260 \mathrm{~nm}$. The IR spectrum showed absorption bands at 3426, 2959, $1700 \mathrm{~cm}^{-}$ 1 indicating the presence of $-\mathrm{OH},-\mathrm{C}-\mathrm{H}, \alpha, \beta$-unsaturated $\mathrm{C}=\mathrm{O}$ respectively. Based on GC-MS spectrum, this compound was a mixture and showed the dominant peak ( $1^{\text {st }}$ peak) with $55.16 \%$ purity (Figure $3 \mathrm{a}$ ). Mass spectrum showed molecular ion at $\mathrm{m} / \mathrm{z} 220$ (Figure $3 \mathrm{~b}$ ). In the GCMS chromatogram, there was a dominant peak with an area and $\mathrm{m} / \mathrm{z}$ of 220 . The fragments obtained were $\mathrm{m} / \mathrm{z} 220$, $177,159,133,107,81,55,43$. This compound had a molecular ion of m/z 220 and base peak at m/z 43 with predictions of $\mathrm{C}_{3} \mathrm{H}_{7}$.

The ${ }^{13} \mathrm{C}-\mathrm{NMR}\left(\mathrm{CDCl}_{3}\right)$ spectrum of isolated compounds showed 15 carbon atoms (Figure 4a). The spectrum displayed carbon signals attributed to four methyl groups ($\delta_{\mathrm{c}} 16.3$ (C-5), 21.3 (C-10'), 18.3(C-9'), 35.2 (C-7'), three methylenes $\left(\delta_{c} 32.0\left(C^{\prime}-5\right.\right.$ '), 26.1(C-4), 49.4(C-6'), four alkene carbons, and the presence of $\alpha, \beta$-unsaturated carbonyl (193 ppm) two methines $\left(\delta_{\mathrm{c}} 41.8\left(\mathrm{C}-8^{\prime}\right), 56.0(\mathrm{C}\right.$ 4'). The ${ }^{1} \mathrm{H}-\mathrm{NMR}$ spectrum of isolated compound (Figure 4b) showed four signals of terminal methyls $\left(\delta_{\mathrm{H}} 0.83-0.85\right.$ (H-10'), 0.92-0.93 (H-9') , 0.83-0.85 (H-7'), 1.48 (H-5) three signals of methylenes $\left(\delta_{\mathrm{H}} 1.07\left(\mathrm{H}-5^{\prime}\right), 1.16-1.22(\mathrm{H}-\right.$ $\left.6^{\prime}\right), 2.26-2.31(\mathrm{H}-4)$, three signals of methines $\left(\delta_{\mathrm{H}} 2.01\right.$ -
2.07 (H-1') 1.69-1.92 (H-4'), 2.20-2.22 (H-8'), two singlet signals of vinyl protons that also indicated the presence of $\alpha, \beta$-unsaturated protons at $\delta_{\mathrm{H}} 6.57\left(\mathrm{H}-2^{\prime}\right), 6.50(\mathrm{H}-3)$ and one singlet signal of aldehyde hydrogen $\left(\delta_{\mathrm{H}} 9.34(\mathrm{H}-1)\right.$. This compound was proposed as 2-ethyl,1,3-(2'-menthene) propenal, a sesquiterpene aldehyde compound (Figure 4.C).

\section{Cytotoxic activities}

All fractions and isolated compounds were tested for cytotoxic activity on breast cancer cells (T-47D) and hepatocarcinoma cells (HepG2). All the fractions showed cytotoxicity with $\mathrm{IC}_{50}<100 \mu \mathrm{g} / \mathrm{ml}$ on $\mathrm{T}-47 \mathrm{D}$ cell lines, with similar cytotoxicity values, were observed on fractions I-III against HepG2 cells ( $\mathrm{IC}_{50}<100 \mu \mathrm{g} / \mathrm{ml}$ ) (Table II). Fraction III was found to has the lowest $\mathrm{IC}_{50}$ values against both cell lines with $\mathrm{IC}_{50}<60 \mu \mathrm{g} / \mathrm{ml}$. The isolated compound obtained from fraction III exhibited cytotoxic activity against T-47D cell line with $\mathrm{IC}_{50} 48.58 \pm 0.96 \mu \mathrm{g} / \mathrm{mL}$. This compound was considered to have weak cytotoxicity. Based on NCI standard, a single compound has potent cytotoxicity with $\mathrm{IC}_{50}<4 \mu \mathrm{g} / \mathrm{ml}$ (Kuete 2018).

The isolated compound was proposed as sesquiterpene aldehyde. Further research is still needed to investigate biological activity of sesquiterpene aldehyde. Based on previous studies, several types of sesquiterpenes were reported to have cytotoxic activities, such as sesquiterpene lactone, sesquiterpene glucoside, and guaiane type sesquiterpene. The alpha beta-unsaturated lactone group in the sesquiterpene lactone is a reactive partial structure. This functional group can cause an alkylation reaction with cysteine amino acid residues in enzymes and proteins which induce apoptosis in cell cancer (Bosco and Golsteyn 2017). Fissipalins A-F, Sesquiterpene glucosides were isolated from the leaves of Fissistigma pallens showed cytotoxicity against HT-29, A-2058, and A-549 cell lines. Fissispallin A showed the most potent activity with the $\mathrm{IC}_{50}$ values less than $1.5 \mu \mathrm{M}$ in all tested cancer cell lines (Thinh et al. 2020). Chamaejasmins A is a guaiane-type sesquiterpene that isolated from the root of Stellera camaejasme. This compound showed cytotoxicity in Hela cell line with $\mathrm{IC}_{50} 6.3 \mu \mathrm{M}$ (El-Desoky et al. 2020). L.domesticum is a member of Meliaceae family. This family has been reported to contain various compounds that are cytotoxic in various cancer cells. Limonoid compounds (5R, 6R, 7S, 13S, 17R) -6-hydroxy-7- (benzoyloxy) -21,23epoxy-4,4,8-trimethyl-24-norchola-1,14,20,22- tetraene-3one [15] was isolated from seeds of $A$. indica. This compound showed potent cytotoxic activity in human gastric cancer (AZ-521) and induce apoptosis. Through western blot, this compound activated pro-apoptotic proteins such as caspase-3,5,8, Bid and AIF (Passos et al. 2019). Compounds 3',4',5,7-tetrahydroxy-3-methoxy flavone from Baccharoides schimperi are cytotoxic in epidermal carcinoma (KB) and ovary carcinoma (SK-OV-3) cancer cells with $\mathrm{IC}_{50}$ values of $22.79 \pm 0.79 \& 30.18 \pm 1.26 \mu \mathrm{M}$ (Ahmed et al. 2018). Aglapervirisin A isolated from A.perviridis has cytotoxic activity against HepG2 cancer cells with $\mathrm{IC}_{50} 0.014 \mu \mathrm{M}$ arrest (An et al. 2016). Meliarachin $C$ compound isolated from $M$. azederach has 
cytotoxic activity against leukemia cell culture HL-60 with $\mathrm{IC}_{50} 0.65+0.12 \mu \mathrm{M}$ (Akihisa et al. 2013). Tonasindiynes $\mathrm{C}$, polyacetylenes compound was isolated from $T$. sinensis root bark. This compound has cytotoxic activity on osteosarcoma (MG-63) cancer cells with an $\mathrm{IC}_{50}$ value of $5.52+0.31 \mu \mathrm{M}$ (Xu et al. 2020).

In conclusion, the fractions of $L$. domesticum fruit peel and the isolated compound showed cytotoxic activity on T47D and HepG2 cells. The isolated compound was identified as a sesquiterpene aldehyde 2-ethyl,3-(2'menthene) propenal. Further research is needed to explore the mechanisms of cytotoxic activity.

\section{ACKNOWLEDGEMENTS}

The authors highly appreciate the Ministry of Higher Education of the Republic of Indonesia for research funding (Grant No. 3163/UN1.DITLIT/DIT-LIT/PT/2020). This study is part of the first author's dissertation.

\section{REFERENCES}

Ahmed S, Al-Rehaily AJ, Ahmad MS, Yousaf M, Nur-e-Alam M, Thomas J, Khan SI, Khan IA. 2018. Cytotoxic and anti-inflammatory activities of the chemical constituents isolated from Baccharoides schimperi DC. S Afr J Bot 114: 9-13. DOI: 10.1016/j.sajb.2017.10.007.

Akihisa T, Pan X, Nakamura Y, Kikuchi T, Takahashi N, Matsumoto M, Ogihara E, Fukatsu M, Koike K, Tokuda H. 2013. Limonoids from the fruits of Melia azedarach and their cytotoxic activities. Phytochem 89: 59-70. DOI: 10.1016/j.phytochem.2013.01.015.

An FL, Wang JS, Wang H, Li Z-R, Yang M-H, Luo J,Kong L-Y. 2016 Cytotoxic rocaglate derivatives from leaves of Aglaia perviridis. Sci Rep 6: 20045. DOI: 10.1038/srep20045.

Bahuguna A, Khan I, Bajpai VK, Kang SC. 2017. MTT Assay to evaluate the cytotoxic potential of a drug. Bangladesh J Pharmacol 12 (2): $115-$ 18. DOI: 10.3329/bjp.v12i2.30892.

Bosco A, Golsteyn RM. 2017. Emerging anti-mitotic activities and other bioactivities of sesquiterpene compounds upon human cells. Molecules 22 (3): 459. DOI: 10.3390/molecules22030459.

El-Desoky AHH, Eguchi K, Kato H, Kishimoto N, Misumi S, Watanabe T, Tsukamoto S. 2020. Chamaejasmins, cytotoxic guaiane sesquiterpenes from the root of Stellera chamaejasme L. Fitoterapia 146: 104714. DOI: 10.1016/j.fitote.2020.104714.

Fadhilah K, Wahyuono S, Astuti P. 2020. A Bioactive compound isolated from duku (Lansium domesticum Corr) fruit peels exhibits cytotoxicity against T47D cell line. F1000Research 9: 3. DOI: 10.12688/f1000research.21072.1.

Kee ME, Khoo HE, Sia CM, Yim HS. 2015. Fractionation of potent antioxidative components from langsat (Lansium domesticum) peel. Pertanika J Trop Agric Sci 38 (1): 103-12.

Klungsupya P, Suthepakul N, Muangman T, Rerk-Am U, Thongdon AJ. 2015. Determination of free radical scavenging, antioxidative DNA damage activities and phytochemical components of active fractions from Lansium domesticum Corr. Fruit. Nutrients 7 (8): 6852. DOI: 10.3390/nu7085312.

Konda JP, Siampa JP, Tallei TE, Kepel BJ, Fatimawali. 2020. Aktivitas antioksidan ekstrak metanol biji langsat (Lansium domesticum var. Pubescens) dan duku (Lansium domesticum var. Domesticum) dengan metode DPPH. Jurnal Ilmiah Sains 20 (2): 113. DOI: 10.35799/jis.20.2.2020.28835. [Indonesian]

Kuete V, Ndontsa BL, Nguekeu YMM, Çelik I, Mbouangouere R, Karaosmanoğlu O, Tane P, Sivas H. 2018. Ardisinol III, a Naturally occurring alkenyl methyl resorcinol displayed cytotoxic effects in carcinoma cells. Investig Med Chem Pharmacol 1 (2): 1-6. DOI: 10.31183/imcp.2018.00014.

Labibah Q, Tun KNW, Aminah NS, Kristanti AN, Ramadhan R, Takaya Y, Abdullah CAC, Masarudin MJ. 2021. Cytotoxic constituent in the fruit peel of Lansium domesticum. Rasayan J Chem 14 (2): 13361340. DOI: $10.31788 /$ rjc.2021.1426044.

Manosroi A, Jantrawut P, Sainakham M, Manosroi W, Manosroi J. 2012. Anticancer activities of the extract from longkong (Lansium domesticum) Young Fruits. Pharm Biol 50 (11): 1397-1407. DOI: 10.3109/13880209.2012.682116.

Marfori ES, Kajiyama SI, Fukusaki EI, Kobayashi A. 2015. Lansioside D, a new triterpenoid glycoside antibiotic from the fruit peel of Lansium domesticum Correa. J Pharmacogn Phytochem 3 (5): 140-143.

Matsumoto T, Kitagawa T, Teo S, Anai Y, Ikeda R, Imahori D, Ahmad HSB, Watanabe T. 2018. Structures and antimutagenic effects of onoceranoid-type triterpenoids from the leaves of Lansium domesticum. J Nat Prod 81 (10): 2187-2194. DOI: 10.1021/acs.jnatprod.8b00341.

Mayanti T. 2009. Kandungan Kimia dan Bioaktivitas Tanaman Duku. UNPAD Press, Bandung. [Indonesian]

Pascual ME, Carretero ME, Slowing KV, Villar A. 2002. Simplified screening by TLC of plant drugs. Pharm Biol 40 (2): 139-43. DOI: 10.1076/ phbi.40.2.139.5849.

Passos M, Carvalho AR, Boeno SI, das Virgens LdLG, Calixto SD, Ventura LBT, Lassounskaia E, Braz-Filho R, Vieira IJC. 2019. Terpenoids isolated from Azadirachta indica roots and biological activities. Revista Brasileira de Farmacognosia 29 (1): 40-45. DOI: 10.1016/j.bjp.2018.12.003.

Rudiyansyah, Alimuddin AH, Masriani, Proksch P. 2018. New tetranortriterpenoids, langsatides A and B from the seeds of Lansium domesticum Corr. (Meliaceae). Phytochemistry Letters 23: 90-93. DOI: 10.1016/j.phytol.2017.11.019.

Susilo, Suciati R. 2016. Studies of morphological and secondary metabolites variety of mosses (Bryophyta) in Cibodas, West Java. Int J Adv Res 4 (12): 1397-1402. DOI: 10.21474/ijar01/2536.

Thinh NS, Bich Thu NT, Ngoc TM, Khoi NM, Tai BH, Kiem PV, Minh CV, Nhiem NX, Seo Y, Namkung W, Park SJ, Kim SH. 2020. Cytotoxic sesquiterpene glucosides from Fissistigma pallens. Phytochem 172: 112255. DOI: 10.1016/j.phytochem.2019.112255.

Tsuchiya A, Makita Y, Takashi K, Koyano T, Kowithayakorn T, Ishibashi M, Arai MA. 2020. Isolation and evaluation of cardenolides from Lansium domesticum as notch inhibitors. J Nat Med 74 (4): 758-766. DOI: 10.1007/s11418-020-01432-7.

Xu WJ, Li JH, Zhou M, Luo J, Jian K-L,Tian X-M, Xia Y-Z, Yang L, Luo J, Kong L-Y. 2020. Toonasindiynes A-F, new polyacetylenes from Toona sinensis with cytotoxic and anti-inflammatory activities. Fitoterapia 146: 104667. DOI: 10.1016/j.fitote.2020.104667.

Zulfikar, Putri NK, Yusuf M, Maharani R, Anshori JA, Supratman U, Mayanti T. 2020. 3-Hydroxy-8,14-Secogammacera-7,14-Dien-21One: A new onoceranoid triterpenes from Lansium domesticum Corr. Cv kokossan. Molbank 2020 1: 2-6. DOI: 10.3390/M1157. 